\title{
Book Review: A Comprehensive Guide to Cognitive Therapy Techniques
}

\author{
Michael S. Greenberg, PhD \\ University of Pennsylvania
}

Follow this and additional works at: https://jdc.jefferson.edu/jeffjpsychiatry

Part of the Psychiatry Commons

Let us know how access to this document benefits you

\author{
Recommended Citation \\ Greenberg, PhD, Michael S. (1987) "Book Review: A Comprehensive Guide to Cognitive Therapy \\ Techniques," Jefferson Journal of Psychiatry. Vol. 5 : Iss. 1 , Article 10. \\ DOI: https://doi.org/10.29046/JJP.005.1.011 \\ Available at: https://jdc.jefferson.edu/jeffjpsychiatry/vol5/iss1/10
}

This Article is brought to you for free and open access by the Jefferson Digital Commons. The Jefferson Digital Commons is a service of Thomas Jefferson University's Center for Teaching and Learning (CTL). The Commons is a showcase for Jefferson books and journals, peer-reviewed scholarly publications, unique historical collections from the University archives, and teaching tools. The Jefferson Digital Commons allows researchers and interested readers anywhere in the world to learn about and keep up to date with Jefferson scholarship. This article has been accepted for inclusion in Jefferson Journal of Psychiatry by an authorized administrator of the Jefferson Digital Commons. For more information, please contact: JeffersonDigitalCommons@jefferson.edu. 


\title{
Book Reviews
}

\section{A Comprehensive Guide to Cognitive Therapy Techniques}

\author{
HANDBOOK OF COGNITIVE THERAPY TECHNIQUES \\ Rian E. McMullin, Ph.D. \\ New York, W.W. Norton, \\ 1986,356 pages, $\$ 34.95$
}

\section{Michael S. Greenberg, Ph.D.}

In recent years, cognitive therapies have received increasing respect and acceptance by practitioners and researchers as viable alternatives to psychoanalysis, humanistic psychotherapy, and behavior therapy. Based upon the pioneering work of Albert Ellis (1), Aaron Beck (2-4), and Donald Meichenbaum (5), among others (6), an increasing number of controlled outcome studies have demonstrated their effectiveness in the treatment of depression and anxietybased disorders. Investigators in this area have been recently turning their attention to cognitive treatments of alcoholism, marital conflict, procrastination, and Axis II personality disorders in an attempt to expand the scope of these interventions. Based upon his own clinical experience and the work of prominent cognitive therapists, author Rian McMullin has compiled a relatively comprehensive set of cognitive interventions into the Handbook of Cognitive Therapy Techniques. McMullin argues that these 75 strategies represent the techniques that he has found most effective in helping patients change from irrational to rational belief systems. This is not a book about cognitive theory and research, although McMullin has drawn extensively from research on basic cognitive processes. It is a relatively practical, step-by-step approach to the application of a diverse set of therapeutic techniques that are designed to promote significant changes in cognition and affect.

The techniques have been organized into seven chapters, with each chapter heading representing a relatively arbitrary rubric to classify the material versus a precise organizational scheme or taxonomy. Each technique includes a statement of basic principles, step-by-step methods of application, examples and clinical case material, evaluative comments, and a list of references in support of

Dr. Greenberg is a post-doctoral fellow and director of research at the Center for Cognitive Therapy, University of Pennsylvania, Philadelphia. 
the strategy. Chapter 1, entitled “Countering Techniques," contains methods to challenge, dispute, and argue against irrational beliefs. These methods are targeted against individual thoughts and beliefs that arise in consciousness as opposed to strategies to change life philosophies, deeply rooted schemata, or conditioned emotional responses. Included in this chapter are coping statements, label shiftings, anti-catastrophic reappraisals, rational beliefs, and other basic tools of rational-emotive therapy, as well as methods that have been based upon the work of theorists such as Lazarus, Beck, Bandura, and Meichenbaum.

The second chapter focuses on perceptual shifting methods that are designed to lead to changes in overall thought patterns, schemata, and gestalten. The chapter opens with an attempt to ground the included techniques in basic research (perception, conditioning, neuroscience, and gestalt psychology). However, McMullin's attempt to provide a conceptual basis for the techniques is confusing, lacks integration, and overwhelms the reader with a plethora of broadly-based speculations. At other times, it is not clear whether a particular technique really deserves its own heading or is simply a variation of another method. In general, however, the present methods provide the clinician with a flexible and broadly-based set of interventions that can be useful in promoting changes in deeply held belief systems. McMullin's emphasis on frequent practice and repetition is a most helpful highlight of a neglected aspect of clinical practice. The section on conditioning techniques contains an extensive compilation of methods that have been used to facilitate anxiety reduction.

Although typically not considered under the province of cognitive therapy, McMullin has included a section on paradoxical methods. Many of these methods are quite creative; however, the application of paradoxical methods can frequently be quite risky and is not for all patients, particularly not with suicidal individuals. The discussion of the risks and caveats of paradoxical methods is insufficient and points to the inherent danger of using a particular technique because it appears creative, novel, or seems like a powerful method of changing the resistant patient. The remaining chapters include methods of logical analysis, irrational beliefs, strategies to monitor patient progress, and adjunctive methods. The latter includes a discussion of the application of cognitive therapy to crisis intervention, an area that deserves considerable attention and future research.

McMullin is quite successful in accomplishing his goal of producing a readily digestible and practical set of cognitive therapy techniques. Hardly any cognitive technique has been omitted, although behavioral methods are, for the most part, ignored. This may be significant, as changes in behavior frequently provide the avenue by which particular irrational beliefs are tested, evaluated, and modified. For the uninitiated, this work does not seem like the most appropriate place to begin serious study of cognitive therapy. The danger is in viewing cognitive therapy as simply a set of techniques or "bag of tricks." Equating cognitive therapy with a collection of therapeutic techniques is as misleading as equating psychoanalysis with the couch, free association, and dream analysis, or 
client-centered therapy with a timely nod of approval. The cornerstone of cognitive therapy is its basic theory that has been derived from laboratory studies of cognition and perception, clinical outcome and process studies, and the clinical knowledge gained through the practice of cognitive therapy. The competent practitioner must have an adequate understanding of the conceptual basis of cognitive therapy, as well as supervised clinical training, before he or she can appropriately apply this or that technique to a particular patient. Technique, conceptual understanding, and an understanding of individual differences and limitations are indispensable ingredients of any legitimate treatment program. Fortunately, McMullin has included a large list of basic readings in cognitive and related therapies, as well as more basic works that he has authored. For those already familiar with cognitive therapy, McMullin's book can help to sharpen and fine tune their clinical skills. However, for those practitioners who do not have this background, it is recommended that they become familiar with the basic works that provide the foundation of cognitive therapy.

\section{REFERENCES}

1. Ellis E: Humanistic Psychotherapy: The Rational-Emotive Approach. New York, McGraw-Hill, 1973

2. Beck AT: Depression: Causes and Treatment. Philadelphia, University of Pennsylvania Press, 1967

3. Beck AT: Cognitive Therapy and the Emotional Disorders. New York, International Universities Press, 1976

4. Beck AT, Rush AJ, Shaw BF, et al: Cognitive Therapy of Depression. New York, Guilford Press, 1979

5. Meichenbaum DB: Cognitive Behavior Modification: An Integrative Approach. New York, Plenum, 1977

6. Lazarus A: The Practice of Multimodal Therapy. New York, McGraw-Hill, 1981 